\title{
AN ANAL YSIS OF USING A MIX OF CLAYEY MATERIALS AND CEMENT MORTAR IN SEALING MASONRY CRACKS
}

\author{
Edivan Ramos de Andrade Filho ${ }^{1}$, Bruna Barbosa Matuti ${ }^{2}$, Jacob Menezes de Souza ${ }^{3}$, Murilo \\ Ferreira dos Santos ${ }^{4}$, Giorgio Arlan da Silva Picanço ${ }^{5}$ and Giovanni Almeida Giordano ${ }^{6}$
}

\author{
1, 2, 3, 4 Northern University Center - UNINORTE, Manaus - Amazonas, Brazil. \\ ${ }^{5}$ National Institute for Space Research - INPE, São José dos Campos - São Paulo, Brazil. \\ ${ }^{6}$ University of Amazon - UNAMA, Belém - Pará, Brazil.
}

Email: edivanramos.filho@gmail.com, bruhmatuti@ outlook.com, jacob.menen@ hotmail.com, mullsantos@gmail.com, giorgio.picanco@inpe.br, giovannigiordano19@gmail.com

Received: Feb 20th, 2020

Accepted: Apr $23^{\text {th }}, 2020$

Published: April $30^{\text {th }}, 2020$

Copyright (C2016 by authors and Galileo Institute of Technology and Education of the Amazon (ITEGAM).

This work is licensed under the Creative Commons Attribution International License (CC BY 4.0).

https://creativecommons.org/licen ses/by/4.0/

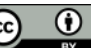

Open Aceses:

\begin{abstract}
This work presents results on the application of a crack treatment by using clayey material in cement mortar. In this way, it is analyzed the behavior of the material applied in the external pathologies of a residential property. Results are presented in order to explain all the stages of the methodology used here, as well as to display some features of the method such as the time of observation, an attribute determined after the application of the technique. From the results, it is observed that the evaluations are in good agreement with what was expected for the technique. Since the developed mortar presented good texture and resistance, it was proven that the material is suitable to be applied in engineering services. It is interesting to observe that the method achieved a good resistance, since in just seven days of healing it became higher compared to the reference trace. This feature is due to the way the trace is executed, since this procedure directly affects the results. Another important benefit obtained with the proposed method is related to the infiltrations, where all points have ceased and the pathologies did not reappear. It is emphasized that the observation was made for a period of one year, an appropriate time for the occurrence of new pathological manifestations. In addition, the new material was applied in the cracks of a fence wall located in a residence at Manaus, Amazonas. In this way, the occurrence of pathologies is probably related to the shrinkage in concrete. This process is due to the loss of volume that occurs in the cement mass, being related to the reduction of excess water from the mixture by the evaporation method. The main objective of using cement mortar is to eliminate this problem in the long-term maintenance, as it causes an aesthetic discomfort. Finally, the application of the method was proven to be suitable for the studied case, since we have observed a satisfactory result. Also, the method application had a low cost since it is derived from a natural material easily found in nature.
\end{abstract}

Keywords: Cement mortar, Clay, Masonry cracks.

\section{INTRODUCTION}

Cracks are pathologies that manifest in masonry walls as openings up to $0.5 \mathrm{~mm}$ [1]. Such anomalies can occur due to design flaws, materials and execution and it is important to analyze what are their main causes, as it is always a general concern when any component of a building fails to meet the minimum requirements for which it was designed. As explained by [2], if the possible causes of cracks are not properly diagnosed and remedied, they can turn into large cracks.
In this regard, these larger cracks are irregularities that affect the expected quality of the building, such as in water tightness, thermal and acoustic comfort, durability and even structural safety. These problems can be caused, according to [3], by: thermal movements, overload performance, foundation settlements, deformations of structural elements, chemical reactions in construction materials, among others. [4], states that cracking is a pathological manifestation that may indicate a dangerous state in which there is a lack of durability on the 
construction, causing the building users to feel uncomfortable about the building security.

It is necessary to make an exact classification of the crack, regarding its origin, its dimensions and, above all, its severity, in order to identify the need to proceed to its treatment and the choice of the appropriate technique and materials for its repair [4].

According to [5], using clay is one of the oldest building techniques in the world, and also comprises one of the first materials to be used for this purpose. From the point of view of sustainability, the clay presents several advantages. Countless ancient civilizations have used different clay construction techniques. In addition, several of them were widely used during the colonization of Brazil, being left aside with the industrialization process. For [6] states that studies related to the application of clay with some type of additive are of great value, since they can enable the development of products with greater resistance and durability, in addition to reducing costs and environmental impacts.

The aforementioned material is present in several compositions of cement mortar. In this way, the use of metakaolinlike calcined clays as pozzolanic material for mortars and concrete has received considerable attention in recent years [7]. Also, the most used clays for the production of pozzolana are kaolinite, montmorillonite and illite [8].

This study analyzes the use of a clay mixture in the cement paste in order to treat cracks, infiltration and aesthetics problems, where one of the main points is to find positive results. Moreover, it is important to mention that a cement mortar with clay mixture can be applied in different areas of civil construction (e.g. glue for deep drainage pipes) [9].

Therefore, the present manuscript aims to verify if the above-mentioned technique presents positive results in the treatment of cracks by performing the following procedures: to examine the cause of the cracks in a sealing masonry, to test the durability and resistance of the applied mortar, to analyze the behavior of mortar and cracks for a period of one year, to verify the advantages and disadvantages of using clay, and to study the behavior of this material applied to the external cracks in a residential property built using non-structural sealing masonry. In short, we present all the stages, procedures and their results after one year of applying the technique.

\section{METHODOLOGY}

This study was conducted performing the steps described below and detailed in the subsections.

The first one consisted of a bibliographic research on the properties of clay, as well as the advantages and disadvantages of using it. As part of the first step, measurements of the strength of this material were obtained by carrying out a compression test in laboratory. Also, the addition of $20 \%$ and $30 \%$ of clay material was made to analyze whether mortar with a quantity greater than $10 \%$ would have the same behavior. From this perspective, it is emphasized that adding a quantity less than $10 \%$ is not the most appropriate, as shown in [9].

The second step was based on studying the causes of cracks on a residential property located in the city of Manaus, Amazonas.

At last, the third step consisted of studying and applying the cement mortar with clay in the pathologies. After this procedure, the behavior of the mortar started to be monitored. From this perspective, possible anomalies and infiltrations were also photo-recorded during the period of one year.
Then, the process of photo collection started in order to record and detail all stages of the methodology. Thus, from the above-mentioned steps, the possible cases of pathological manifestations were identified and presented.

\section{II.1 GENERAL ASPECTS OF CLAY}

The clay is a rock consisting essentially of a group of minerals called clay minerals [10]. For [11] states that this material is originated from the decomposition of rocks. In this way, the types of clay can be classified into primary, formed in the same location as the rocks, or secondary, formed by weathering.

The term sensu lato clay is used to designate a natural inorganic material of fine granulometry, which presents a plastic behavior when mixed to a certain amount of water. From a sedimentological-granulometric point of view, the clay fraction corresponds to the set of particles smaller than $2 \mu \mathrm{m}$ or $4 \mu \mathrm{m}$ [12]. According to [13], some other types of clay material are currently used:

- Kaolin: a clay consisting essentially of kaolinite with a very high refraction index;

- Bentonite: a residual clay resulting from the alteration of volcanic ashes or acidic tufts, with a very fine granulometry and variable color. It is emphasized that the bentonite, due to its properties such as plasticity, impermeability, resistance to compression, and low compressibility has also other applications in civil engineering (e.g. landfill cover, basin waterproofing) [14];

- Common clay: the most common type of clay in nature. This material is mainly used in the manufacture of low-cost ceramic products; and

- Fibrous clays: a type of clay composed of fibrous clay minerals belonging to the group of paligorsquite and sepiolite.

The clay used in this work was collected in a deep drainage construction, placed in the Japiim neighborhood at Manaus, Amazonas. It is emphasized that this site corresponds to the same source of clay described in [9]. In addition, the material used here is characterized as ordinary clay or red clay. In this way, the red clay is originated from physical and chemical weathering over rocks with a greater predominance of iron oxide, which gives rise to particles much smaller than grains of sand.

From that perspective, one of the predominant chemical components of the material used in this work is iron oxide. In civil construction, expanded clay is generally used in the mixture of light concrete due to its low density. In this context, the impermeability is also an important factor. Regarding the common clay, it is generally used for manufacture of ceramic products, but it is worth mentioning that there are two main types according to its use: pottery clay and brick clay [15].

\section{II.2 ADVANTAGES AND DISADVANTAGES OF USING CLAY}

According to [5], clay as a building material has certain advantages and disadvantages. In this context, the use of clay provides a healthy environment, since it is able to absorb and lose moisture faster than any other building material. Also, due to its thickness and density after molding, the clay reduces the transmission of noise, and when compared to other materials it is more economical than the industrial ones. It also provides low maintenance and long durability, because after being built and sealed the clay should not need maintenance for about 10 to 20 years. However, the disadvantages of using clay in civil 
construction are related to the fact that it is not an impermeable material, so the contact with water must be avoid in order of prevent cracks occurrence.

Moreover, the employment of expanded clay as a coarse aggregate brings numerous benefits, such as thermal and acoustic comfort, also being considered as an economic and ecological solution in the use of concrete [16].

\section{II.3 THEORETICAL ASPECTS OF BUILDING PATHOLOGIES}

According to [17], cracks can be caused by several factors. Some of the most common causes are: excessive load on walls, temperature variations, retraction of blocks, and concrete elements.

The masonry cracks in buildings are a sign that something is wrong, which may compromise water tightness, sound insulation and even the building structure. Even though there are no risks in the structure, the cracks have a very negative aesthetics effect on the residents, and it is natural to them to demand the solution of the problem [19].

For [20] states that the openings are classified according to their thickness in: crack, large crack, disruption, slit, or breach. This classification is presented in Table 1:

Table 1: Classification of pathologies according to their openings.

\begin{tabular}{|c|c|}
\hline Pathology & Opening $(\mathrm{mm})$ \\
\hline Crack & up to 0.5 \\
\hline Large crack & 0.5 to 1.5 \\
\hline Disruption & 1.5 to 5.0 \\
\hline Slit & 5.0 to 10.0 \\
\hline Breach & $>10.0$ \\
\hline
\end{tabular}

According to [21], the pathologies can occur due to the human error during the design phase, the execution phase or even during the use phase. For instance, in a survey conducted in Belgium by Reygaerts, it was found that out of 1200 cases the most common causes of cracking were [22]:

- $35 \%$ corresponding to the movement of the reinforced concrete structure;

- $25 \%$ due to the thermal influence;

- $25 \%$ due to the hygrometric influence; and

- $15 \%$ due to the movement of the foundation.

According to the [23] DNIT 083/2006 standard, cracks and large cracks are specific and unavoidable phenomena of reinforced concrete that can occur in each of the three following phases: plastic phase, hardening phase and hardened concrete phase. These pathologies are generated by several factors, where one of the most recurrent is the retraction process. In this way, the retraction movement start by the loss of moisture in the coating at its early stages, causing the appearance of internal tensile stresses that are relieved through the crack's occurrence.

\section{II.4 APPLICATION OF THE TECHNIQUE}

A conventional one-floor residence was chosen to study and analyze the pathologies and the application of the developed mortar. The masonry wall is sealed and located outside the house, and already had certain anomalies along its entire length, such as cracks and infiltrations (Figure 1).

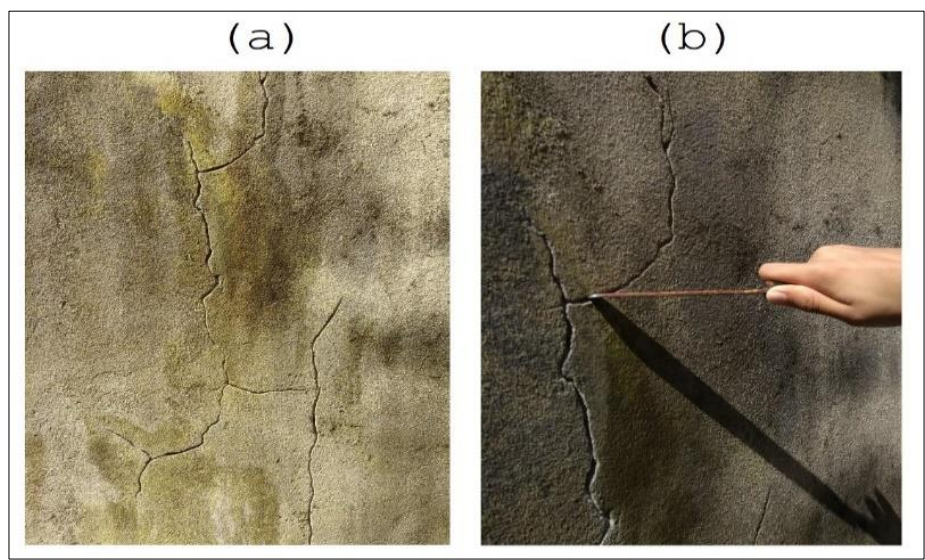

Figure 1: (a) Occurrence of cracks in the masonry wall, and (b) crack depth measurement.

Source: Authors, (2020).

From the above process, a set of photos was taken in order to present the treatment step by step, from its initial state to its finishing. Started the process of treating pathologies, the first step was to scarify it, as it is necessary to stimulate the opening of the fissure so that the applied product enters more easily and more efficiently (Figure 2).

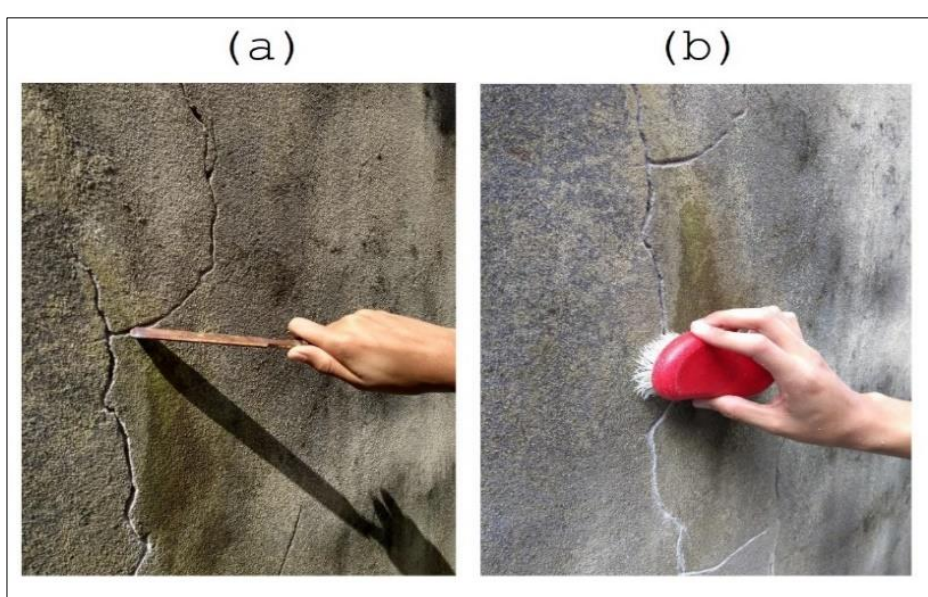

Figure 2: (a) Scarification process, and (b) surface cleaning step. Source: Authors, (2020).

Then, the surface was cleaned with water, a fundamental procedure to remove the dirt and dust that remained on the surface after scarifying it. Thus, the product can have a good adhesion on the masonry (Figure 3).

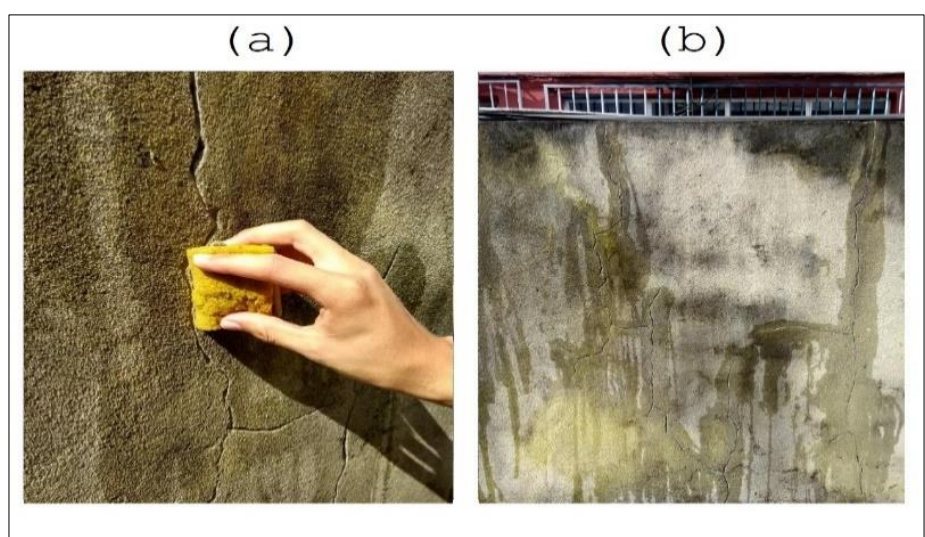

Figure 3: (a) Cleaning with water and sponge, and (b) cleaning completed.

Source: Authors, (2020). 
Then, the mortar with ten percent of clay was applied. In order to facilitate the application, a silicone bag was used (Figure $4)$.

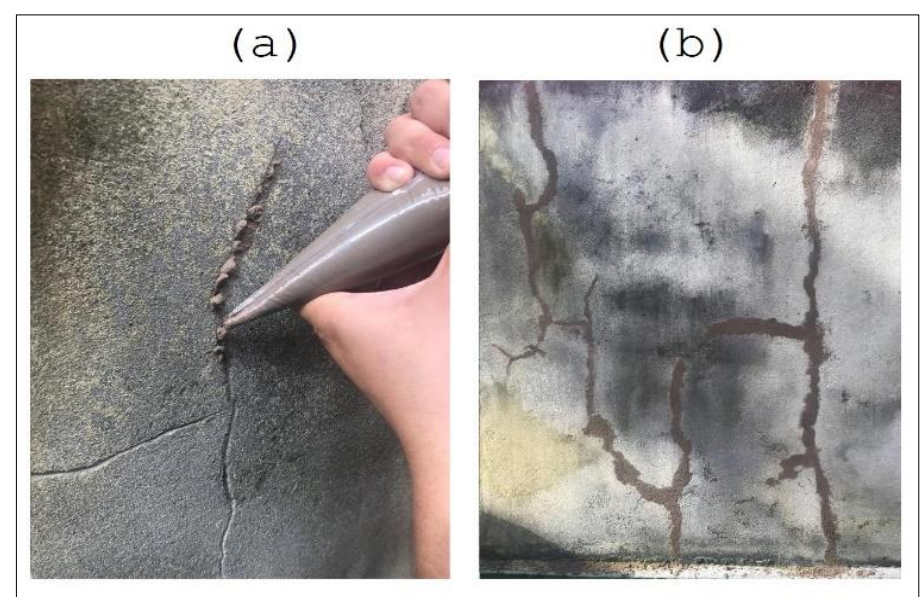

Figure 4: (a) Mortar application, and (b) completed application. Source: Authors, (2020).

The wall was sanded three months after the mortar application. It is emphasized that this is the time necessary for the mortar behavior to be analyzed. Afterwards, the masonry was painted (Figures 5 and 6).

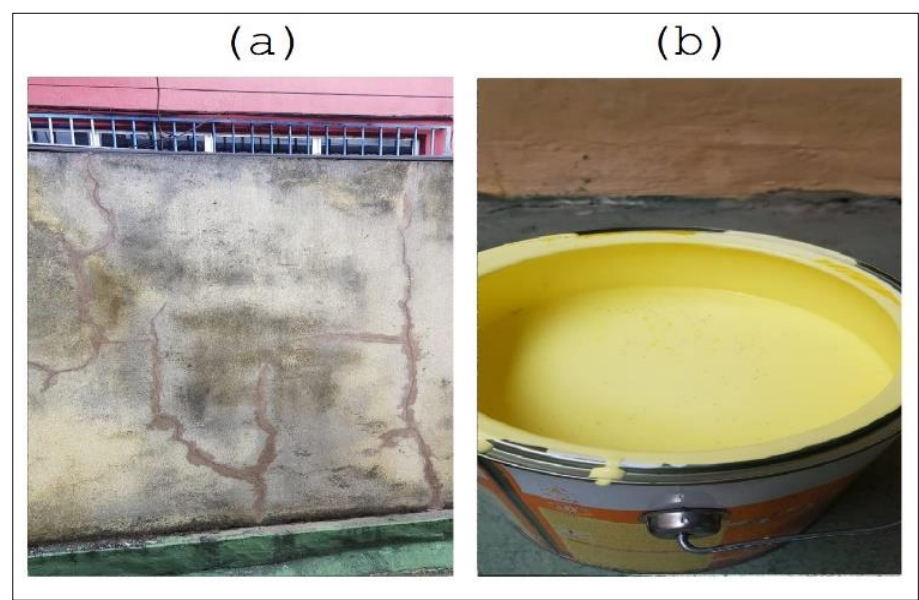

Figure 5: (a) After sanding, and (b) used ink - Iquine brand Source: Authors, (2020).

\section{(a)}

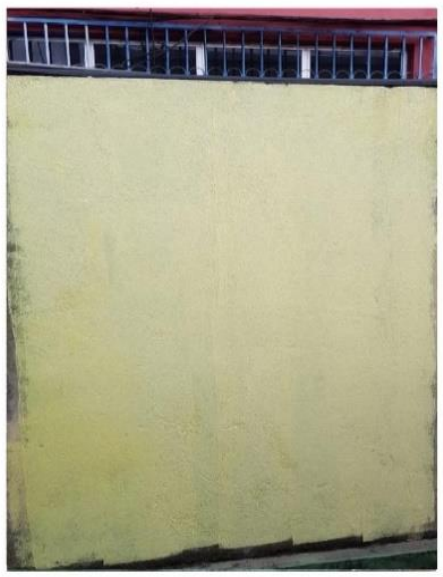

(b)

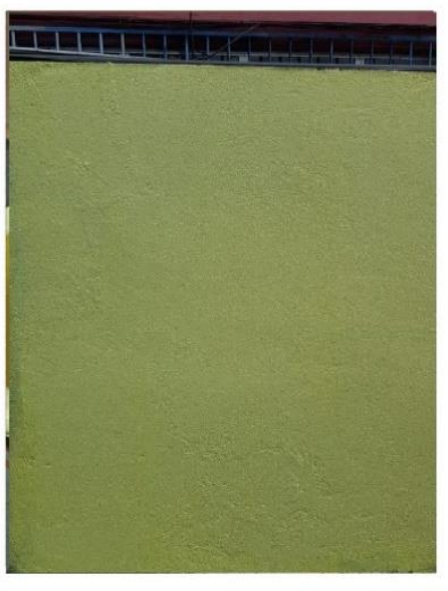

Figure 6: (a) First coat of paint, and (b) masonry finish. Source: Authors, (2020).
After the service was completed, the behavior of pathologies in the masonry was observed for a period of one year.

\section{II.5 STAGES FOR THE THREATMENT}

The main steps necessary to carry out the treatment are summarized below:

- Scarification;

- Surface cleaning;

- Mortar application;

- Sanding;

- Masonry painting.

\section{II.6 TESTS PERFORMED}

According to [24], the main characteristic of concrete is its resistance to compression, which is determined by the test of specimens submitted to compression. This test also allows to obtain other characteristics of the material, such as the longitudinal strain module contained in NBR 6118/2010.

In this way, the compressive strength was performed over cylindrical specimens of $10 \mathrm{~cm}$ in diameter and $20 \mathrm{~cm}$ in height, or $5 \mathrm{~cm}$ in diameter and $10 \mathrm{~cm}$ in height. The test was based on increasing the tension gradually until the rupture of the material, according to NBR 5738/2015. In order to execute the procedure, the cylinder must be filled with concrete, in four layers. Each layer must receive 30 strokes with a metal rod, where the strokes must not touch the lower layer.

After compacting the last layer, the surface must be leveled with a spoon. After a 24-hour period, the removal of specimens from molds is performed. Each sample must be identified and must go immediately to wet curing, so that water reduction and alteration of the results in the resistance tests are avoided. The rupture of the specimens is usually performed in 7 and 28 days. After the days have passed, the specimens are taken to a press where their resistance to compression is measured. From the result of this test, it is verified whether the concrete reached the resistance determined in the project or not.

\section{RESULTS AND DISCUSSION}

This section presents the obtained results, as well as an analysis of the procedures based on their respective standards and technical instructions as it was obtained from DNIT Standard 083/2006 - Treatment of cracks and large cracks.

The studied masonry wall presented pathologies of less than $0.5 \mathrm{~mm}$, being classified as cracks. The cause of these anomalies can be attributed to several factors, such as the retraction of the mortar, and also to the components used to build it. It is worth mentioning that after the construction of the original wall was completed, its structure collapsed. Thus, it was necessary to hire a new service to reform the wall. Certainly this second work presented problems of execution, which leads to be another probably cause for the development of these pathologies. Consequently, analyzing the results obtained after the application of the material on the sealing masonry, it was proven that the developed mortar performed well, since the cracks and infiltrations did not reappear after the procedure (Figure 7). 


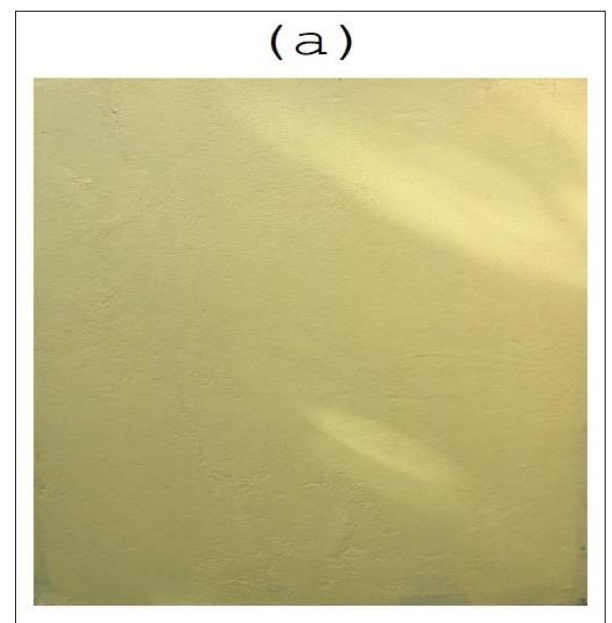

Figure 7: (a) Masonry wall after 1 year of observation. Source: Authors, (2020).

The compressive strength test was performed at 7 and 28 days (Figure 8). The tests presented satisfactory results, since it was achieved the minimum fck, equal to $25 \mathrm{Mpa}$. For each dosage, two specimens were made with $10 \%, 20 \%$ and $30 \%$ of clay. These specimens were planned to be broken after 7 and 28 days, and the trace used as a reference was the same as used by [9] (Table 2).

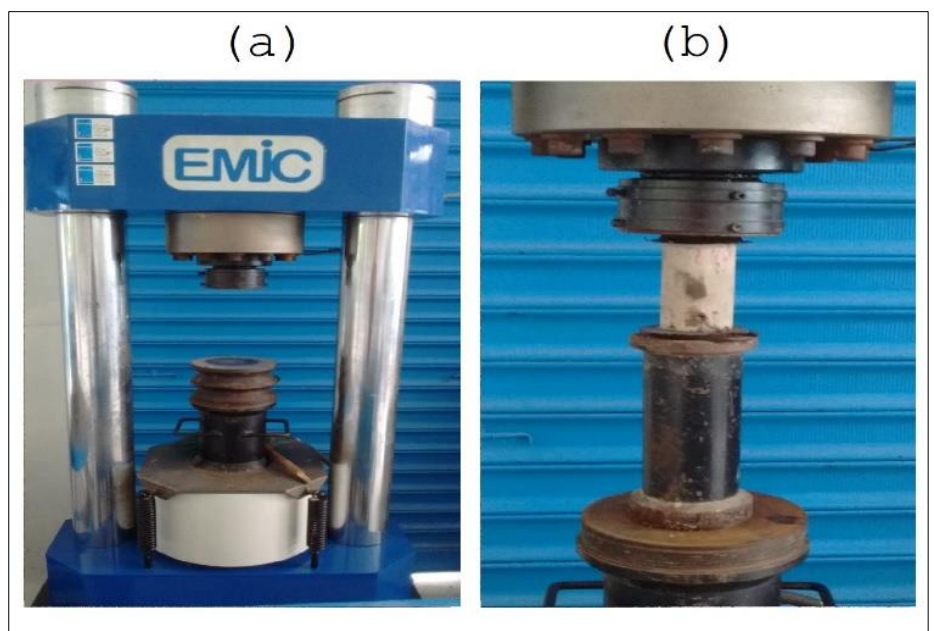

Figure 8: (a) Compression test press, and (b) developed specimen. Source: Authors, (2020).

Table 2: Mass of the materials to be used on concrete, with $10 \%$ of clay.

\begin{tabular}{|c|c|}
\hline \multicolumn{2}{|c|}{ Dosage - 10\% Clay } \\
\hline Material & Mass $(\mathrm{Kg})$ \\
\hline Water & 0.25 \\
\hline Cement & 1.00 \\
\hline Sand & 0.50 \\
\hline Additive & $7 \%$ \\
\hline Clay & $10 \%$ \\
\hline
\end{tabular}

Source: Authors, (2020).

According to the procedure found in [9] Menezes (2018), it was used an amount of clay with $8 \%$ and $10 \%$ in the mortar, since it was proven that the $10 \%$ dosage is more efficient. In the same way, a dosage was made by using the aforementioned trace, and two more dosages adding $20 \%$ and $30 \%$ in order to check whether mortar with a higher amount of clay material would have the same effect. In this way, after the compression test, the results of the resistance of each dosage after 7 days of curing were obtained (Figure 9).

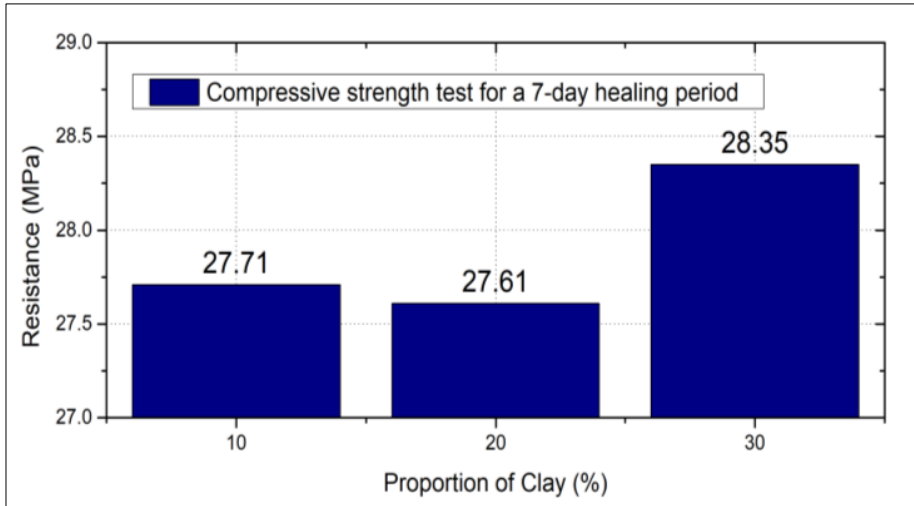

Figure 9: Mortar strength after 7 days of wet curing. Source: Authors, (2020).

As mentioned above, it can be observed that in just 7 days of wet curing the mortar had a good result, reaching over $25 \mathrm{Mpa}$ in all dosages. Then, the specimens were tested with 28 days of wet curing, where it was obtained a very satisfactory result (Figure 10).

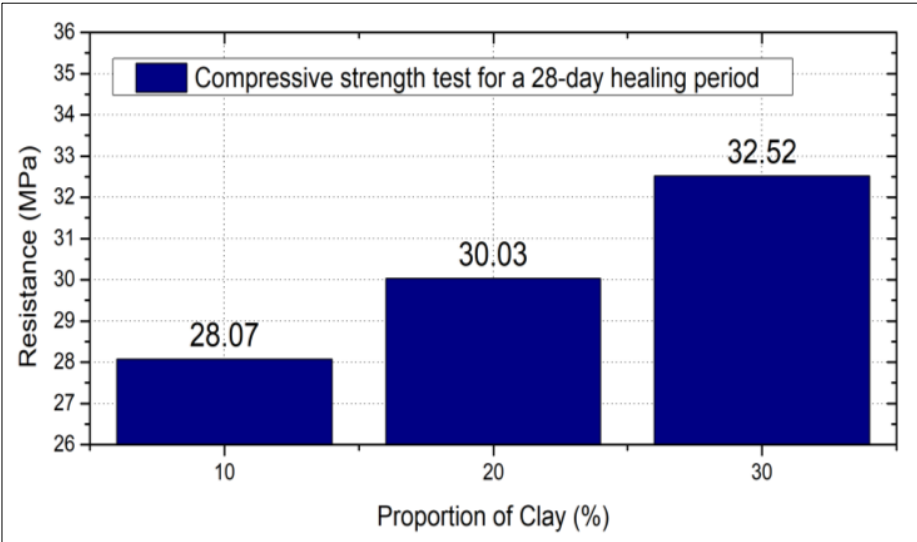

Figure 10: Mortar strength after 28 days of wet curing. Source: Authors, (2020).

Therefore, comparing with the results of [9] (Table 3), it can be observed that the resistance data presented in this study (Table 4) proved to be superior. In this context, the Tables 3 and 4 present the compressive strength results regarding the dosage with $10 \%$ of clay. It is emphasized that only the additive was removed from the reference trace, as it is a material with a high economic cost. However, the other dosages were applied strictly.

Table 3: Compressive strength.

\begin{tabular}{|c|c|}
\hline Days & Compressive strength - CPII-s4-40 (MPa) \\
\hline 7 & 7.96 \\
\hline 14 & 17.65 \\
\hline 28 & 28 \\
\hline
\end{tabular}

Source: [9].

Table 4: Compressive strength with an average dosage of $10 \%$.

\begin{tabular}{|c|c|}
\hline Days & Compressive strength - (MPa) \\
\hline 7 & 27.71 \\
\hline 28 & 28.4 \\
\hline
\end{tabular}

Source: Authors, (2020). 
In this regard, [9] states that the use of clay material together with a superplasticizer additive in mortar is highly effective, since this experiment presented good results and can contribute to future works in civil construction.

\section{CONCLUSIONS}

The clay material can be used in several areas, such as in the manufacture of ceramics, in semiconductors for computer equipment, in the manufacture of bricks, manufacturing of cement and others. In ancient times, houses were made of clay, but since this material becomes plastic when in contact with water, it was necessary to use a sealant. It is interesting to mention that the clay material was widely used mainly due to its low economic cost, as well as due to its ease of being found in nature. After the tests and analyzes on the addition of clay in mortar, it was observed that both in terms of strength and consistency, the result was quite positive. Consequently, aiming to find a good solution for the treatment of cracks, it was observed that they did not reappear after the employment of the method. In this way, it is emphasized that they were observed and analyzed during a period of 1 year, as described in the methodology section. Starting from the concept of cracks as pathologies, it is emphasized that these anomalies can be caused by the concrete retraction process, and this action occurs due to the loss of water in the mortar. However, the anomalies were observed in the passive form, that is, it would not evolve in size or depth. It is worth mentioning that the infiltrations ceased, since the pathologies existing in the upper part of the masonry were treated with the developed mortar, what solved the problem. Taking into account what was previously mentioned, [9] only used the proportion of $10 \%$ of clay in the dosage. In this context, our study proved that it is possible to use an additional amount, such as $20 \%$ or $30 \%$, as it does not interfere in its properties. In addition, the mortar with $30 \%$ of clay presented a good resistance to compression and good workability. The compression test was carried out at the Konkrex concrete plant (at Manaus, Amazonas) by using a hydraulic press, as shown in the methodology section.

The mortar used in this study proved to be more appropriate for the studied case that one used in [9]. A plausible explanation would be due to not using the additive in the dosage, the way in which the materials were mixed, as well as the density of the specimen. It is worth mentioning that there were no difficulties in applying the material on the masonry wall.

We concluded that this material is effective on treating masonry cracks, and can be also used as glue for deep pipes, confirming what was stated by [9]. In addition, mortar has good resistance to compression, and its use is more economically accessible when compared to acrylic or plastic sealants, canvas, waterproofing materials and other treatments, as it can be found in nature easily and due to its easy applicability. Finally, this material should be more explored as it can contribute even more in civil construction, since it presented good results.

\section{ACKNOWLEDGMENTS}

The authors thank all those who were involved in the execution of this study, especially to the coordination of the Civil Engineering undergraduate course at the Northern University Center (UNINORTE/LAUREATE). Also, the authors would like to thank the Konkrex company for providing access to the Building Materials Laboratory, as well as to the equipment and materials used here. G. A. S. Picanço thanks CAPES/MEC (Grant 88887.351778/2019-00)

\section{REFERENCES}

[1] Mapa da Obra (2019). Fissura: como resolver essa patologia em paredes. Disponível em: www.mapadaobra.com.br/capacitacao/fissura-paredes. Acesso em 15 out. 2019.

[2] Montefusco, E. (2019). Mapa da obra: Fissura: como resolver essa patologia em paredes.

[3] Lourenci, C. R. B. (2019). Diagnóstico das manifestações patológicas em empreendimento hoteleiro de pequeno porte no município de Imbituba: levantamento, avaliação e reparação das principais ocorrências. 72 p. Monografia (Graduação em Engenharia Civil) - Universidade do Sul de Santa Catarina (UNISUL), Tubarão, Brasil.

[4] Jâcome, C. C., Martins, J. G. (2005). Identificação e tratamento de patologias em edifícios. 119 p. Relatório Técnico Universidade do Estado do Amazonas, Manaus, Brasil.

[5] Sustentarqui (2018). Vantagens da construção com terra. Disponível em: www.sustentarqui.com.br/vantagens-daconstrucao-com-terra. Acesso em 09 out. 2019.

[6] Araújo, R. D. E. A. (2011). Desenvolvimento de concretos de baixo impacto ambiental para a produção de elementos construtivos: contribuições à sustentabilidade das edificações. In: $53^{\circ}$ Congresso Brasileiro do Concreto: IBRACON, Florianópolis,

SC, Brasil.

[7] Oliveira, M. P., Barbosa, M. P. (2005) Potencialidades de um caulim calcinado como material de substituição parcial do cimento Portland em argamassas. Revista Brasileira de Engenharia Agrícola e Ambiental, 10(2), DOI: 10.1590/S141543662006000200034.

[8] Santos, P. S. (1992). Ciência e Tecnologia de argilas. 408 p. 1(2), Edgard Blucher, São Paulo, Brasil.

[9] Menezes, J.S. (2018) Análise da implantação de material argiloso e aditivo superplastificante em argamassa. Journal of Engineering and Technology for Industrial Applications, 16(4), DOI: $10.5935 / 2447-0228.20180084$.

[10] Coelho, A. C. V., Santos. P. S. (2005), Argilas Especiais: O Que São, Caracterização e Propriedades. Química Nova, 30(1) 146-152.

[11] Toledo, M. C. M. (2009), Intemperismo e pedogênese. In Geologia, São Paulo, SP, Brasil.

[12] Junior, M. C. (2008). Argila para cerâmica vermelha. In: Rochas \& minerais industriais: usos e especificações. Rio de Janeiro, RJ, Brasil.

[13] Meira, J. M. L. (2001). Argilas: o que são, suas propriedades e classificações. Relatório Técnico. Visa Consultores. Oeiras, Portugal.

[14] Luz, A.B., Oliveira, C.H. (2008). Argila - Bentonita. In: Rochas e Minerais Industriais - usos e especificações. Rio de Janeiro, RJ, Brasil.

[15] Ferraz, F. (2015). Argilas como matérias-primas cerâmicas.

[16] Junior, A. R. S. (2018) Efeitos da variação do agregado graúdo em dosagem de concreto. 46 p. Monografia (Graduação em Engenharia Civil) - Centro Universitário UNIFAAT. Atibaia, SP, Brasil. 
[17] Duarte, R. B. (1998). Fissuras em alvenarias: causas principais, medidas preventivas e técnicas de recuperação. 45 p. Relatório Técnico. Fundação de Ciência e Tecnologia - CIENTEC. Porto Alegre, RS, Brasil.

[19] Tramontin, A. P., Moreno Junior, A. L., Oliveira, C. R. (2005). Avaliação experimental dos métodos de prevenção de fissuras na interface alvenaria de vedação e pilar de concreto. Revista IBRACON de Estruturas e Materiais, 6(5), DOI: 10.1590/S198341952013000500005.

[20] Oliveira, A. M. (2012). Fissuras e rachaduras causadas por recalque diferencial de fundações. 10 p. Monografia (Graduação em Ciência e Tecnologia) - Universidade Federal Rural do Semiárido (UNIFERSA). Mossoró, RN, Brasil.

[21] Almeida, R. S. (2005). Patologia na construção Civil.

[22] Muci, D. W. S., Netto, J. R. B., Silva, R. A. (2014). Sistemas de recuperação de fissuras da interface alvenaria de vedação estrutura de concreto: comparativo entre os processos executivos e análise de custo. 98 p. Monografia (Graduação em Ciência e Tecnologia) - Universidade Federal de Goiás (UFG). Goiânia, GO, Brasil.

[23] Norma DNIT 083/2006 (2006). Tratamento de trincas e fissuras - especificação de serviço.

[24] Carvalho, R., Filho, F. (2010). Cálculo e detalhamento de estruturas usuais de concreto armado: segundo a NBR 6118:2003. 415 p. Edufscar, São Carlos, SP, Brasil. 